\title{
PRESENT DAY SCHOOL READERS IN RAPPORT WITH THE DRAMATIC WORKS OF A ONCE-BANNED ALBANIAN AUTHOR
}

\author{
Besa Shingjergji \\ besashingjergji@gmail.com \\ University of Elbasan "Aleksandër Xhuvani", Albania \\ (a) $\odot \Theta \Theta$ \\ Hektor Ciftja \\ hciftja@yahoo.co.uk \\ University of Elbasan "Aleksandër Xhuvani", Albania
}

\begin{abstract}
The process of reading, rereading, scrutinizing, re-scrutinizing and appraising an author's work is not finite; moreover it is very dynamic and full of suprises. No doubt that the appraisal and re-appraisal is too complex, including cultural, literary, gender and genre components. This becomes more obvious when referring to an author whose works had been locked up in library stacks during the whole 45 years of totalitarian rule in Albania, and whose appraisal process cannot help facing up to the critical thinking led by biased politicization.

In this study the appraisal of the works of one of the most outstanding Albanian writers of the 30s of the twentieth century, Etëhem Haxhiademi, will be done by presenting them in rapport with the present-day school, pre-university and university level readers. This reappraisal is conducted with a cold logic, devoid of the vindictive political principles which brought the distorted evaluation of the authors' works, as it happened for many other authors as well, and is striving to place the writer into the system of the genuine literary values.

Once the reader's inquisitiveness has been satisfied, even after reading a less-known or, moreover, an oblivious or banned literary work, he/she begins reading and rereading it, looking closely into it, essaying to find a proper place for this work in the general system of the national, inter-balkanic and international literary values.

E. Haxhiademi's literary work was known by an older generations of readers whose esthetic satisfaction it brought forth was confined in their consciousness: it was unknown or partly known, not by direct reading but by several interpretations of others, by a middle generation of readers who displayed a certain artistic uncertainty and indifference. However, nowadays it is intently being studied although in excessively fragmentary ways and in many cases even unsuitable ones, by the younger generation of readers who should have a more motivated curiosity for divulging its real values.

In the history of the Albanian literature, as well as in the other East European Countries, the authors' biographies and especially their political aspects, were used as selective criteria to appraise authors and their works, instead of being pure cognitive and studying means.

This study intends to reveal the present-day school readers' affirmative attitudes or even the non-affirmative ones, regarding Haxhiademi's literary works, in the process of re-dimensioning the author's values and those of his literary works.
\end{abstract}

Key words: school-level reader, banned author, classical tragedian, author's re-appraisal, critical thinking, and complex messages. 
While analyzing a writer with a complex life and whose literary works were locked up in library stocks during the whole 45 years of totalitarian rule in Albania, one cannot help facing up to the critical thinking led by biased politicization. In the history of the Albanian literature, the authors' biographies and especially their political aspects were transmuted into selective criteria to appraise authors and their works, instead of being pure cognitive and studying means.

In these terms, Marxist literary criticism - based on non-literary criteria, are shown to be excessive in distinguishing authors and their works, so leaving central figures of the Albanian Literature out, for years on end. Consequently, the use of criteria based on the principles of class struggle and political attitudes and engagements, left many writers of Albanian Literature in oblivion, even making many of them fall prey to denigration, such as Faik Konica, Gjergj Fishta, Ernest Koliqi, Etehem Haxhiademi, Martin Camaj, Bilal Xhaferri, Kasem Trebeshin and so on.

To write about an author's works without taking his/her life into consideration is difficult, whereas to identify the writer's works with his personal life, particularly with his political attitudes and engagements, is scientifically wrong. Both the writers' biography's and their works should be considered as part of their whole perplexity and complexity and not judged merely in black and white. If the selective criteria of the class struggle were true there would have been no Honore de Balzac, Leo Tolstoy etc.

This paper strives to reappraise the work of one of the most outstanding Albanian writers of the thirties, as well as to reveal the rapport the present-day school readers have established with the author's works. This reappraisal will be done by avoiding the vindictive political principles which brought forth the distorted evaluation of the author's work, as it also happened for many other authors.

The process of reading, rereading, scrutinizing, re-scrutinizing and appraising an author's work is not finite; moreover it is very dynamic and full of surprises. Literary works and their authors do not cease sending messages, regardless of the time of the initial source of their emission. Once the reader's inquisitiveness has been satisfied, even after reading a less-known or, moreover, an oblivious or banned literary work, it is the conscious curiosity which motivates rating that work within a system of values, among the other books which more or less belong to our favorites. Moreover, and in a more wider socio-cultural ambit, once the reader begins reading and rereading the literary work and looks closely into it, he/ she attempts to find a proper place for this work in the general system of national literary values.

This can be said about Etëhem Haxhiademi's dramatic plays, the author termed by the contemporary press at the time he lived and worked as the "Sophocles of Albania", an epithet given to him as the creator of seven utterly Albanian Tragedies.

His dramatic plays create rapport with the readers of every age. E. Haxhiademi's literary work has been known by the older generation of readers for whom the esthetic satisfaction it brought fourth was retained in their consciousness: it was unknown or partly known, not by direct reading but via several interpretations by others, by a middle generation of readers who display a certain artistic uncertainty and indifference. However, nowadays it is intently being studied although in excessively fragmentary and unsuitable ways by the younger generation of readers who should have a more motivated curiosity for divulging its real values. 
E. Haxhiademi is among the most distinguished creators of the Albanian Tragedy. He is known as the creator of seven tragedies with mythological and historical subjects. E. Haxhiademi's tragedies occupy a relatively substantial place in the insufficient development of the literary genre of drama in the 1920s and 30s. In 1924 he wrote the tragedy "Ulysses" (in Berlin), in 1926 he wrote, the tragedy "Achilles" (in Vienna) whereas in 1928 he wrote the tragedy "Alexander" (Lushnje, Albania). The three tragedies were published in Tirana in 1931. Later on E. Haxhiademi wrote and published the tragedies "Pirro" (1934), "Scanderbeg" (1935) "Diomed" (1936) and "Abel" (1938).

The artistic geography of E. Haxhiademi's tragedies seizes wide spaces, even crossing inter-balkanic borders. Relevant to the nature of the classic tragedy, the antiquity or medieval subjects even those of the biblical pre-history, became a function of the concerning issues which found parallels in the phenomena, ideas and problems featuring in the reality of the time they were written. Through his tragedies E. Haxhiademi intended to create artistic realities which would be esthetically acquired by the readers. By means of this esthetic acquisition they would become more refined in relations with each other, with their nation, their state and the moral - qualities which they would inherit and cultivate for future generations. The messages in his tragedies are complex because the realities from which they originate are complex, too. They source from the royal courts of the antiquity, from the deities and semi-deities tables to the Middle Ages or the XV century, from the Illyrian or Albanian Kings to the Greek or biblical mythology.

A question comes naturally in this regard: Why did E. Haxhiademi deal with the genre of tragedy? He was interested in the theater from a very young age, as the author himself would reveal many years later. Since his early youth, the desire to write tragedies was never uprooted. During his studies and while being in contact with the western culture he got to know the Greek and Latin authors. The writer expresses his sympathy for antique art and the colossuses of antiquity which had become his favorites. E. Haxhiademi wrote tragedies not because he didn't know about progressive contemporary art but because of the low level of the Albanian drama which he thought to evolve in the classicist form. As far as those tragedies attracted spectators or readers it happened that besides the author's endowments, wants, cultural formation, education, and effects of the classicist culture, there was a necessity of the reality he lived in for the evolvement of the genre of classicist tragedy in Albania.

E. Haxhiademi is a classicist tragedian appearing in the modern stage of Albanian Literature. This shows an abnormal evolution of the genre of Albanian drama as compared to genres of poetry and prose. The reasons promoting the author to deal with this literary genre lie in the fact that at the time E. Haxhiademi was writing his plays, the Albanian theater was making its first steps. The theater had not yet attained sustainability, not only because of the obvious insufficiency of literary material but even because of the lack of tradition in that field. In Elbasan - the author's hometown, there were theatrical activities which set off his first endowments and wants. In the period E. Haxhiademi wrote and displayed his tragedies that theater was functioning on an amateur basis. Both the possibilities and means available were insufficient. This was why E. Haxhiademi chose to evolve the classic structure. His tragedies lack complicated dramatic actions making these tragedies more manageable, practically easier to be realized in terms of stage-management. Conscious to fill in a gap in Albanian culture and incited by the fact that the theatrical performances were in their first steps as well as for other reasons he chose to evolve the classicist tragedy model. 
E. Haxhiademi's persistent endeavor to restore classic tragedy, in the time when tragedy itself had surpassed its flourishing period, might be explained with his endeavors to give another push to one of the less-developed genres of the Albanian literature: dramaturgy. This genre, because of its conventionality in the Albanian literature could not be developed otherwise but in the roads trampled down by others. It could be developed solely by following the models which were considered, even by the European literature, as examples of perfection.

The classicist tragedy, with its profound educative tendencies, would teach and cultivate the Albanians, who had fallen backwards because of their history, with its spirit of emancipation. Also, the persistence of the messages sourcing from the Albanian Renaissance, to divulge the antiquity and autochthony of the Albanian people remained one of the main tasks of the Albanian nationalist intelligence. The Albanian people needed to get artistically aware of their spiritual relations with the antique world which had almost faded during centuries of the Ottoman occupation.

Beyond the national and political interests, the antique and mythological world is attractive with its beauty, the variety of forms and the profundity of the messages it transmits. By focusing on the esthetic kernel of his works, E. Haxhiademi becomes a bearer of important messages to present-day realities. As well as in the classicist tragedy, E. Haxhiademi's tragedy cast into balance:

1. The great interests of major characters such as the kings and queens, commanders and soldiers, princesses and princes, well-known leaders whose actions have been enhanced by the powerful passion of being omnipotent. This passion becomes the cause of their tragic failures.

2. The everlasting passions of humans with their greed to rule the others, with their love and vengeance - all bringing them down to their final destruction. In cases these passions were fair, namely restrained by reason, they bore the virtue, whereas to the contrary, they sowed and spread vice.

The classicists were all moralists with their work. They accepted this inclination quite openly and considered their creativity as bearing real values which provided education through splendor. E. Haxhiademi abided by this viewpoint, as well, and he never hesitated to avow it, while addressing the readers in one of his own works titled "Abel", which was written to express a moral thesis. In general, and in his work as a whole, E. Haxhiademi tried to realize the notorious esthetic principle of the classicists: instructing and educating by means of attraction deriving from the praise of virtue in the fight against vice. By imitating every aspect of the classicist tragedy in his works E. Haxhiademi tried to reflect not only the feelings of greed featured in royal power but other feelings as well, such as love, parental compassion, and nobility - always ruled by reason as the only force protecting and setting the virtue in its proper place (Xhiku, 1989). These observations, which surely, are neither lonesome nor exhaustive, seem to sufficiently support the conclusion that E. Haxhiademi's tragedies made up the most genuine classicist phenomenon in the literary evolution in Albania in the first half of the XX century.

For decades on end, the author's work was left in oblivion for non-literary motives. The shades of multi-annual underestimating attitudes towards his works made the dust of oblivion on his creativity prevail even until today. 
The critical thinking about E. Haxhiademi's tragedies, displayed both in the pre-war (1920-1944), or the post-war press (1945-1990) as well as in the studies after the '90's has affected reader opinion time and again.

In the pre-war studies (1920-1944), there were contradictory opinions about E. Haxhiademi's tragedies, even excessively negative, both appraising and critically underestimating. There were also cases when the same scholars displayed two-fold opinions both appraising and underestimating at the same time. The majority of them did not welcome his work with the sympathy and esteem it deserved. Moreover, in that time E. Haxhiademi's works had incited polemics and had divided scholars in two groups, the so-called haxhiademists and anti-haxhiademists, (as termed by Vangjel Koça). One of the contemporary scholars explains the lack of sympathy for E. Haxhiademi's works by the existence of the different literary clans as well as with the fact that there were certain literary opinions which did not appreciate mythology and required the literary works to address the concerns of the time. Moreover, some fanatics termed Greek mythology as an anti-national subject (Koça, 1937).

Some other critics or writers criticized the author for adopting subjects from a very ancient time, for dealing with outdated problems and for presenting pale characters. Also there were opinions that E. Haxhiademi's tragedies are an amalgam of the tragic antique poets, they aren't distinguished for originality and their characters are not well-elaborated (Shuteriqi, 1937).

The criticism also emphasized the distortion of the historical events in E. Haxhiademi's works, doubting the artistic genuineness of the events. According to the critical thinking of that period, great gaps are noticed in E. Haxhiademi's tragedies, among which, the characters should have been better elaborated and analyzed since the fine elaboration of the characters is a condition of classicist tragedies (Shundi, 1936). Nebil Çika, in his leaflet "Renaissance of Arbenia" harshly criticized E. Haxhiademi's drama "Alexander". He hinted that the historical drama, such as the tragedy which colligated with "Alexander the Great", should not distort the historic events and facts. The Author of the Tragedy was criticized for failing to correctly keep to the historic events and facts. N. Çika pretended that E. Haxhiademi's drama is not perfectly good and does not deserve to be staged (Bukoniku, 1930). Such a criticism tried to belittle the real values of this drama, and, since it came from people who didn't have the necessary formation, it really sounds unfortunate. It is clear that the critical thinking of this period suffers from subjectivism and nihilist partiality.

In the post-war studies (1945-1990), this dramatist was rarely mentioned. However, in some studies it was mentioned that he remained in the circle of outdated subjects and styles. In this period the first attempts were made to apply the principle of historicism in the literary sciences, which created possibilities to judge each literary work in its own course of crystallization, in the frame of the creative development of its author as well as in the frame of historic-literary events, as a phenomenon of evolvement of the literature in a certain period of time. However, the critical thinking - oriented to excessive ideological clues, didn't allow the historicism to be completed. It artificially created gaps in reflecting certain authors by partially or completely denying them.

In the 50's, it was the vulgar sociologism which harmed the critical thinking, namely, the overestimation of the content while neglecting the esthetic aspects (Kodra, 1996). Literary criticism did not exist as such in those years, which means that it did not have a well-defined methodology, failed to know the structural and semiological experiences and never 
approached the text it was supposed to analyze. The non-professional criticism brought forth the exclusion of great writers because of political and ideological reasons, or due to the ignorance and the envy of the critics. The consequence was the exclusion of Gjergj Fishta, Faik Konica, Ernest Koliqi, E. Haxhiademi, Zef Skiroi, Martin Camaj, Vincenc Prendushi, Kasem Trebeshina, on the pretext that they were "reactionaries", "anti-people" and "dangerous" intellectuals.

E. Haxhiademi was also excluded as a literature author because of the principles related to his biography. Writers such as Gj.Fishta, F.Konica, E.Koliqi were en bloc considered as reactionary writers in the school texts, whereas E. Haxhiademi is not mentioned or is mentioned rarely. His work could be easily left in shadow and wrapped up with the mist of oblivion, because E. Haxhiademi did not have the glory of the three aforementioned writers even in the time his works were first published (Matraxhiu, 1991). And it would have gone on like that until Alfred Uçi - the official esthete and the most consequent representative of the "social-classism school", treated the "reactionary" groupings of writers "en bloc", in his edition "Mythology, Folklore, Art", in which he also reserved some specific pages for E. Haxhiademi (Uçi, 1982).

The aforementioned "reactionary" group was accused of having used mythology to disguise the political reality during the reign of King Zog in Albania. They were also accused that their literature lacked the real national spirit, distorted and falsified mythology, history, and even the folklore as well as did not assume a critical attitude towards religion. Professor Uçi tried to find the "proofs" to certify those accusations and others, easily in the E. Haxhiademi's works, in most cases by citing the titles of his tragedies, although sometimes the arguments have even fallen in antagonism with themselves. So, this esthete became an example of incorrectness and antagonism.

The critical thinking of that period was idealogized and would ultimately lead to distortions, inexactness and contradictions. In the post-war studies and up to the 1990 this dramaturge was rarely mentioned. However, in some texts he was evaluated as the representative of the Albanian dramaturgy, as follower of the classicist current and as a weaver of contemporary tragedy. For the school-level readers of the period, the name of this author was almost unknown, he could be found solely in the stocks of some private libraries.

The post 90 's criticism has been trying to study the playwright's values and rank him alongside the others creators of the Albanian literature, after the long secrecy that covered E. Haxhiademi's works and life during the reign of the dictatorship in Albania. Laws exist in the world of art just as they do in nature. The literature critics and historians have to discover and evaluate the literary works based on these laws. Objectivity is the target to be achieved by the critics. Compared to the forerunning critical thinking in the press of the time, the antagonistic evaluations sourced from two controversial esthetic concepts on the role of the art and poetry which have always been encountered in different moments of historical developments or in different nations.

The first viewpoint is termed the utilitarian viewpoint: It requires any intentional art to help resolve the most concerning problems of that specific time, an art in which the respective society finds itself. In the relatively new Albanian literature, (from the national Renaissance on ward), because of the need for the solution of national problems and the patriotic engagements to this end, this viewpoint has been prevalent. In the 1930s, with the worsening of the social wounds, a new group of writers and poets came on the scene. 
(Matraxhiu, 1991) This kind of art has often been linked with the momentum of political passions which create the illusion of a success, but which was not a long-lived one. With the change of political situations a part of those artistic works - being affected by the utilitarian idea are lost. Only those works survive which consciously or unconsciously have captured what features a whole epoch and have had an admirable artistic level, alongside the treatment of the social and political momentum processes.

Scholar Bardhyl Matraxhiu gives his own opinion regarding the viewpoint about the rapport of art and social developments, in his account "The critique of Tragedy or the Tragedy of criticism" in the "Nentori" magazine in 1991, in which he considers the engagement of art and politics as the worst evil. This extreme development in the post-war Albanian literature went so far that, the writers were termed as assistants of the party, or were openly asked to resolve problems related to collectivization, industrialization, collectivism of the livestock herds, on behalf of the "partisanship" and "political engagement to resolve the cardinal problems of the time".

The second viewpoint, denies the first, namely, it is against the rapport of the literature and art with the actual and concrete concerns of life, with political engagements, etc. It should avoid what for the moment looks intentional and useful. What these writers acknowledge as useful and as creativity criteria are solely the laws of beauty. Objects of art are considered solely as phenomena of nature that have a perpetual esthetical character. To them, every intentional avoidance from the high mission of art leads to the degradation of the artistic quality. In the first sight this kind of art looks like disengaged art but it is not as such (Matraxhiu, 1991).

A said achievement of the "new criticism" is the perception of artistic work as a living being, which cannot be separated in two parts, (with disintegrated content and form). However, the gaps and contradictions in the appraisal of E. Haxhiademi's works source from the author's pre-destined fate, since he was condemned as a reactionary writer and his works should mandatorily be considered as reactionary, too. However, polemics on various issues makes the literary work more evolved and the readers more informed.

In the post-nineties studies, E. Haxhiademi's tragedies have been appraised for the evolvement of the ideas, the ways the drama plots have been woven, the mastery in presenting conflicts, salient tragic characters which render incarnate the grandiose or lowliness qualities, for the well-evolved verses, and for the elaboration of motives that feature humans as a whole.

Scholar Aurel Plasari supports a dissentient attitude towards the literary criticism made in the contemporary press, which effected by the intolerance and the ignorance in the domain of literary criticism, labeled E. Haxhiademi with such terms as "a fascist", "isolated from reality" and "haunted classicist" and so on.

This scholar shares the thought that these dramatic works bear the weight of "anachronism" which looks quite natural with the passing of the time, like many of the other literary works of the time in general.

According to him, generations would be ungrateful if they forgot that E. Haxhiademi is the absolute creator of the Albanian Tragedy, the one who left a consolidated work behind and raised the Albanian Dramaturgy to the levels of European drama. He appraised the author for keeping the artistic life in Elbasan a live (Plasari, 1991).

What ways were used to obliterate the author from remembrance? 
His works were banned and lost in silence - both ways that might have given results but they could not, because:

1. The Kosovan and foreign criticism, free from dogmatism cites E. Haxhiademi when illustrating the rapports of the Albanian mythology with literature or when referring to the beginnings of the Albanian theater.

2. E. Haxhiademi's works radiate with their saliant simplicity and individuality.

Therefore, this writer could not be banished into silence, so a third way was used to eliminate him, by attacking his work literally. In most cases, the failings on one side and the risings on the other have been considered as a testimony of the work's vitality. These ups and downs give the readers the possibility to somewhat play the role of the critical judge to raise a literary creator to the pedestal of honor or to downgrade (Matraxhiu, 1991).

The works by this author are being made aware of by the younger generations of readers, but in an excessively fragmentary way. The readers should have a greater curiosity to discover their values. The work by this author was made known for the first time in the post 90s literature textbook of Albanian pre-university education, but only partly. In the school curricula it is only "Abel" that has been presented so far, a drama which transmits many important moral ideas to the present-day readers.

The tragedy "Abel" is the simplest work by E. Haxhiademi, both in terms of the subject and its dramatic action, but splendid and complicated in terms of the psychological analyses. The biblical symbolism used in this work makes the present-day reader curious to discover the father - mother, children - parents, and brother - brother rapports.

In this dramatic text an alteration of the biblical myths occurs. The events descend from divine settings to terrestrial ones. This way of building the narration serves the author to bring important ideas in the family, society, nation and international ambits. By taking advantage of the mythological subjects, the author helps the readers to find parallels to contemporary developments, ideas and problems with those of biblical pre-history. The present-day reader at school level is expected to analyze the style and language used by the author, in terms of acquisition and interpretation. This will help the readers to understand the alteration of the biblical myths in a Tragedy. In the foundations of "Abel" we find motifs taken from the Old Testament. The narrative has been inspired from the legends over the biblical figures. By approaching the drama plot with the biblical myths the readers can deduce various essential coincidences.

The biblical data has been altered by the author in his own way. This means that the biblical subjects have been sufficiently transformed. The utilization of the mythological topics and biblical motifs serve to treat important ethical-moral, social and political problems. The author does present the myth but creates an artistic work via creating characters and conflicts, by means of which crucial ideas of all times have been transmitted.

In this tragedy by E. Haxhiademi, the present-day reader finds that presents are given to parents, different from the biblical stories in which sacrifices were made to the gods. So the divine elements have been avoided and the biblical tragedy becomes a family-like story. The lack of deities and their actions in the tragedy does not support a mythological treatment by the author, but a historic and realist one (Matraxhiu, 1991).

The actual reader at the university level has been involved in more-in-depth study of both the work and its author. The object of this study is the author's dramatic structure, con- 
tent, the ideas the author transmits through time as well as the features of dramatic speech. According to the readers' viewpoint there are other conclusions about the author's work, different from the biased critical thinking.

1. E. Haxhiademi was a proponent of the classic and classicist tragedy experiences but realist elements and the romantic spirit are present in his works, as well. The elements of the antique tragedy are identified by the ways the dimensions of the heroes' actions and features are aggrandized; the ways the passions are emphasized and the tragic consequences are displayed, in which even gods interfere time and time again. The realist elements are spotted in the intentions to profane mythological characters by deepening into their psychology as well as by illustrating tragic conflicts with pure social causes. The romantic spirit is displayed in the idealization of the feelings of love and the dream for freedom.

2. In his tragedies, this author retraced plots that had never been treated in the Greek and Latin tragedy or in that of the European classicism, even though he took the literary material from mythology and ancient times.

3. He is one of the most outstanding connoisseurs and disseminators of antique culture in Albania. His works connect us with the Balkan ancient and autochthon people's mythology and history. He appraises antiquity not only for the splendor and the importance of the characters it provides but as an Albanian, as well. The author becomes a disseminator of this spirit, so that the Albanians felt fellow-citizens and creators of the ancient Balkanic culture, which lies at the foundations of European culture.

4. E. Haxhiademi divulged the historical moments in his thematic treatments which, by means of the myths and symbols realize figurative meanings, especially with parabolas which often shift their initial meaning. Modern clues are also shown in his works, given into these initial meanings, so that their ideas and messages come into the Albanian space to relate with its reality.

5. The transmission of the myths by the author, in the incessant existence of mankind, was done in the form of important humanist ideas. The long-familiar mythological figures have not been presented in their original relations and conflicts, but in renewed conflicts in order to reveal his own ideas.

6. Thematically, his work manages to be closely linked with national problems.

7. The author has been featured as inclined to retrace the classicist tragedy, although this genre had surpassed its flourishing period. This tendency can be explained with his desire to push forward the evolution of the least developed genre of the Albanian language - the dramatic genre.

8. The classicism of E. Haxhiademi's tragedies gives the impression that they go beyond the time in which they are shown both in terms of the writing pathos and the main thematic ideas.

9. By staging his tragedies which have an obvious classicist tendency and a deeply educative content, a spirit of emancipation became possible. So he realized the classicists' well-known esthetic principle: instructing and educating by means of attraction coming from the praise of virtue in the fight against vice.

10. E. Haxhiademi's tragedy, in terms of its literary form preserves the shape of the classicist tragedy in five acts, mainly cultivated by French classicism. By attending to achieve a symmetric harmony and classicist symmetry, it conserves both the number of acts 
and the same number of scenes. E. Haxhiademi's tragedies, despite the featured post-Romanist gaps, mark an important creativity which alongside fulfilling the existent gap in this literary genre contributed to the presentation of the antique and biblical myths in an evolved artistic and re-creative form.

The attractive plots, themes and the tough conflicts create great interpretative possibilities and new perceptions for the present-day readers, gaining incessant meanings.

Tragic characters have also been presented in E. Haxhiademi's works with distinguished virtues or dispirited, ugly, harmful, dangerous characters. The features these characters display are repeated in life and in different times so that the readers can identify them with new phenomenon or visualizations.

No doubt the appraisal or re-appraisal of a literary work is too complex, with cultural, literary, gender and various components. Our literary science is positioning E. Haxhiademi, the writer who has brought new values to the national literature, as well as the whole pleiad of creators in this field, in their proper and deserved place. With his literary works and ideas, this author is returning to the Albanian literature just as writers always do.

\section{REFERENCES}

Bukoniku. (1930, October 29). Shfaqja e dramës Aleksandri i Math dhe kritikat e z. Çika (Letra nga Tirana) [The performance of the drama 'Alexander the Great' and Mr Çika's criticism (Letters from Tirana)]. Kostancë, Edition Shqipëria e re, 443, 3.

Hamiti, S. (2009). Letërsia moderne shqipe [The modern Albanian Literature]. Tiranë: UET Press.

Islami, N. (2003). Historia dhe poetika e dramës shqipe [History and the poetics of the Albanian drama ] . Prishtinë: ARTC.

Koça, V. (1937, March). Viti mendor 1936 [Intellectual Year 1936]. Përpjekja Shqiptare, 1, 202.

Kodra, K. (1996). Letërsia si e tillë, Probleme të vlerësimit të trashëgimisë sonë kulturore [Literature as such, problems with the appraisal of our cultural inheritance]. Tirana: Academy of Sciences.

Mato, J. (2005). Poetika e dramaturgiisë dhe mendimi estetik [The poetics of dramaturgy and the esthetical thought]. Tiranë: Mesonjetorja.

Matraxhiu, B. (1991). Kritikë e tragjedisë dhe tragjedi e kritikës [Critique to tragedy and the critique's tragedy]. Nëntori, 7, 98-102.

Merxhani,B. (1936, October). Diomedi, Etëhem Haxhiademi - tragjedi me pesë akte ['Diomed', Etëhem Haxhiademi - a tragedy with 5 Acts]. Përpjekja Shqiptare, 1, 62-64.

Merxhani, B. (1937, May). Rreth tragjedisë "Skënderbeu" (Një polemikë letrare) [About the tragedy "Scanderbeg" (A literary polemics)]. Përpjekja shqiptare, 8, 121-126.

Plasari, A. (1991, June 9). Portret i vonuar i tragjikut Etëhem Haxhiademi [Delayed portrait of the tragedian Etëhem Haxhiademi]. Drita, 2 , 11-12.

Plasari, A. (1992, January 12). Ideologjia e dashurisë përballë ideologjisë së urrejtjes: Duke reflektuar mbi "Abelin" e Haxhiademit [The ideology of affection confronting the ideology of hatred: Reflecting over 'Abel' by Haxhiademit]. Drita, 2,79.

Shundi, S. (1936, July 1) Gjana qi mbesin dhe gjana qi vdesin: “Skënderbeu”, tragjedi me 5 akte prej Etëhem Haxhiademit [Things that persist and things that expire: "Scanderbeg", a tragedy with 5 Acts by Etëhem Haxhiademit]. Arbënia, 327, pg.3.

Shuteriqi, Dh. (1937). Për një drejtim të ri letrar [About a new literary course]. Përpjekja Shqiptare, 7, 93.

Shtylla, B. (1944, October). Tragjedit e Haxhiademit [Haxhiademi's Tragedies]. Shkëndija, 4, 123-136.

Spasse, S. (1935, January). Pirrua. Një tragjedi e re e Etëhem Haxhiademit (Shënime letrare) [Pirro. A new tragedy by Etëhem Haxhiademi (Literary notes)]. Rilindja, 3, 9-13.

Xhiku, A. (1989). Nga romantizmi rrjedhave të realizmit. [The romanticism of the flows of realism] . Tiranë: Publishing House of the University books...

Xhuvani, A. (1936, January 4). Një tragjedi e re shqipe. Skënderbeu [A new Albanian tragedy, .Skënderbeu]. Illyria, 37, pg. 3-4.

Uçi, A. (1982). Mitologjia, Folklori, Arti [Mythology, Folklore, Art]. Tiranë: Publishing House “Naim Frashëri”. 